\title{
MICROCEPHALY AND ZIKA VIRUS INFECTION
}

\section{MICROCEFALIA E INFECCIÓN POR EL VIRUS DEL ZIKA}

\section{Beuy Joob ${ }^{1}$, Viroj Wiwanitkit?.}

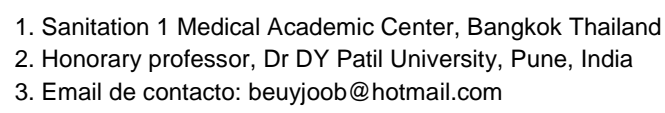

\section{Dear Editor,}

We read the publication on "Analisis temporal y espacial de las muertes infantiles por microcefalia en Argentina (1998-2012)" with a great interest ${ }^{[1]}$. Dipierri and Bronberg concluded that "Esta distribución se relaciona con la mayor pobreza y consanguinidad del norte de la Argentina, factores sinérgicos predisponentes de la ocurrencia de malformaciones congénitas en general y de microcefalia en particular ${ }^{[1]}$." Indeed, the microcephaly becomes the new global issue when the Zika virus emerges. The possible relationship between microcephaly and Zika virus infection is shown in some settings but the opposite findings are generally reported from others. The present report from Argentina might not support the correlation. We would like to share our observation in Indochina where the Zika virus infection is also common. Until present, despite several months of disease emergence, there is still no scientific evidence to confirm the relationship between infection and microcephaly in out setting. Indeed, the asymptomatic nature of Zika virus infection is common in Indochina ${ }^{[2-3]}$ and the lack of occurrence of Zika virus related microcephaly ${ }^{[4]}$ might support the finding in the present study by Dipierri and Bronberg ${ }^{[1]}$.

Keywords: microcephaly; zika viral infection

Estimado Editor, leímos la publicación sobre "Análisis temporal y estacional de las muertes infantiles por microcefalia en Argentina (1998-2012)" con gran interés ${ }^{[1]}$. Dipierri y Bronberg concluyeron que "Esta distribución se relaciona con la mayor pobreza y consanguinidad del norte de la Argentina, los factores sinérgicos predisponentes de la ocurrencia de malformaciones congénitas en general y de microcefalia en particular ${ }^{[1] "}$. De hecho, la microcefalia se convierte en la nueva problema global cuando surge el virus Zika. La posible relación entre la microcefalia y la infección por el virus del Zika se muestra en algunos entornos, pero los hallazgos opuestos generalmente se informan en otros. El presente informe de Argentina podría no respaldar la correlación. Nos gustaría compartir nuestra observación en Indochina, donde la infección por el virus del Zika también es común. Hasta el presente, a pesar de varios meses de aparición de la enfermedad, todavía no hay evidencia científica para confirmar la relación entre la infección y la microcefalia en el entorno. De hecho, la naturaleza asintomática de la infección por el virus del Zika es común en Indochina ${ }^{[2-3]}$ y la falta de ocurrencia de la microcefalia relacionada con el virus del Zika ${ }^{[4]}$ podría apoyar el hallazgo en el presente estudio realizado por Dipierri y Bronberg ${ }^{[1]}$.

Palabras Claves: microcefalia; zika; infección; vírica

Conflict of interest: None

\section{References}

1. Dipierri JE, Bronberg RA. Analisis temporal y espacial de las muertes infantiles por microcefalia en Argentina (1998-2012). Rev Fac Cien Med Univ Nac Cordoba. 2017 Sep 8;74(3):15786

2. Wiwanitkit $S$, Wiwanitkit $V$. Afebrile, asymptomatic and non-thrombocytopenic Zika virus infection: Don't miss it! Asian Pac J Trop Med. 2016 May;9(5):513.

3. Wiwanitkit V. The current status of Zika virus in Southeast Asia. Epidemiol Health. 2016 Jun 16;38:e2016026.

4. Joob B, Yasser F. Phenotypic spectrum of congenital Zika syndrome: a comment on the usefulness of case report. Case Study Case Rep. 2017; 7(2): 29-30. 